\title{
Carbothermal Reduction, Melting Separation, and Structural Analysis of Carbon-bearing Rare Earth Iron Ore Pellets
}

\author{
Xuefeng SHE, ${ }^{1) *}$ Wanli $\mathrm{YI}^{11}{ }^{1)}$ Tengfei MA, ${ }^{1)}$ Zhuo ZHANG, ${ }^{2)}$ Jingsong WANG ${ }^{1)}$ and Qingguo XUE ${ }^{1)}$ \\ 1) State Key Laboratory of Advanced Metallurgy, University of Science and Technology Beijing, Beijing, 100083 China. \\ 2) Surface Chemistry Laboratory of Electronic Materials, Department of Chemical Engineering, Pohang University of Science \\ and Technology (POSTECH), Pohang, 790-784 South Korea.
}

(Received on August 18, 2019; accepted on November 21, 2019)

\begin{abstract}
The slag of rare earth Bayan Obo complex iron ore (REBOCIO) after direct reduction and melting contains a lot of rare earth elements (REEs). In this work, the isothermal reduction and melting separation experiments of REEs-bearing iron carbon composite pellets and the detailed characterization of rare earth (RE) slag were conducted, with the aim at developing knowledge of the reduction mechanism and the behavior of REEs during the direct reduction and melting process. The results indicate that the pellets can be optimally reduced at $1200^{\circ} \mathrm{C}$ for $15 \mathrm{~min}$ with a $\mathrm{C} / \mathrm{O}$ ratio of 1.2 . The $\mathrm{RE}$-containing phases differ depending on the reaction conditions. When the temperature is relatively low at $1100^{\circ} \mathrm{C}$, the major $\mathrm{RE}$ phase in the slag is $\mathrm{Ce}_{4.67}\left(\mathrm{Si} \mathrm{O}_{4}\right)_{3} \mathrm{O}$; while $\left(\mathrm{Ca}, \mathrm{Ce}, \mathrm{La}_{5}\left(\mathrm{SiO}_{4}\right)_{6} \mathrm{~F}\right.$ becomes the dominant $\mathrm{RE}$ phase in the slag at $1400^{\circ} \mathrm{C}$. The main crystalline phase in the air-cooling slag are cuspidine $\left(\mathrm{Ca}_{4} \mathrm{Si}_{2} \mathrm{O}_{7} \mathrm{~F}_{2}\right),(\mathrm{Ca}, \mathrm{Ce}$, $\mathrm{La})_{5}\left(\mathrm{SiO}_{4}\right)_{6} \mathrm{~F}$ and fluorite $\left(\mathrm{CaF}_{2}\right)$. The particle size of the RE phase increases as the cooling rate decreases. In the case of furnace cooling, the RE phase in the slag has a more complete structure, namely hexagonal prismatic. And the RE phase is hexagonal system with space group $\mathrm{P} 63 / \mathrm{m}$ and unitcell parameters $a=$ 9.5908(3) $\AA, b=9.5908(3) \AA, c=7.0268(2) \AA, \beta=90(3)^{\circ}$, and $V=559.75(4) \AA^{3}$.
\end{abstract}

KEY WORDS: Bayan Obo complex iron ore; carbon composite pellet; direct reduction; rare earth slag; crystal structure.

\section{Introduction}

Rare earth Bayan Obo Composite iron ore (REBOCIO), located in the Inner Mongolia of North China, is renowned for the largest rare earths elements (REEs) deposit in the world. ${ }^{1)}$ This ore deposit accounts for $35 \%$ of the rare earth (RE) resources of world the reserves and approximately $80 \%$ of that of China. ${ }^{2-5)}$ However, the low-grade iron ore, the complicated ore type, and the fine particle size of REBOCIO, have resulted in many problems associated with mineral dressing and the blast furnace process. Additionally, REEs are usually recovered as a by-product of other metal ore mining processes because of their low concentration. Most of the RE slag is stacked in tailings dams, which make it difficult to extract and utilize of REEs. Therefore, a new method to realize the sustainable development of the RE industry is urgently required.

In recent years, traditional blast furnace production has been significantly challenged with the gradual reduction of high-grade iron ore and coking coal. As a typical non-coke iron-making process, the rotary hearth furnace is receiving increasing attention because of its advantages, i.e., short processing time, strong application of raw materials and flexible operation process. ${ }^{6,7)}$ The raw material used in the

* Corresponding author: E-mail: shexuefeng@ustb.edu.cn DOI: https://doi.org/10.2355/isijinternational.ISIJINT-2019-519 rotary hearth furnace is carbon composite pellets, which consist of fine iron ore combined with fine carbon powder. Because the iron oxide is directly in contact with carbon, the reduction rate is very high and the production efficiency can become much higher than that of the traditional iron production process. To date, many studies have been carried out to examine the reduction behavior of carbon composite pellets. ${ }^{8-12)}$ A study by Ding et al. ${ }^{13,14)}$ determined suitable conditions for separating of RE slag and iron from REBOCIO. She $e t a l .{ }^{15)}$ put forward the mechanism of slag formation of RE phase. However, few studies about the distribution and migration of elements during the process of reduction and melting separation of the pellets have been reported, and the slag-forming mechanism of rare earth phase remains to be improved. In addition, the existence and structure of the RE phase after slag-iron separation is still controversial; for example, Ding et al. $^{13)}$ believed that it exists as [7(Ca, Ce, $\left.\mathrm{La}, \mathrm{Nd})_{2} \cdot \mathrm{SiO}_{4}\right](\mathrm{F}, \mathrm{O})_{10}$, whereas $\mathrm{Li}$ et al. ${ }^{16)}$ considered it to exist as $\mathrm{RE}_{2} \mathrm{O}_{3}-\mathrm{CaO}-\mathrm{SiO}_{2}$ and $\mathrm{Li}$ et al. ${ }^{17)}$ considered it to exist as $\mathrm{Ca}_{3} \mathrm{Ce}_{2}\left[(\mathrm{Si}, \mathrm{P}) \mathrm{O}_{4}\right]_{3} \mathrm{~F}$. Carbon-bearing pellet reduction and melting separation are complex processes and investigations to further elucidate the behavior of RE elements in the processes will continue into the future.

In the present study, REEs-bearing iron carbon composite pellets were manufactured by a cold isostatic press. The effects of temperature, reduction time, and different $\mathrm{C} / \mathrm{O}$ ratios on the carbothermic reduction rate of these pellets 
were investigated experimentally. The micromorphology changes and phase transformations of the pellets were determined in the process of reduction using scanning electron microscopy (SEM) and X-ray diffraction (XRD), respectively. The melting separation behavior of carbon-bearing pellets and the process of slag formation of the RE phase were investigated. In addition, the crystal structure of the RE phase was analyzed by single-crystal XRD.

\section{Experimental}

\subsection{Raw Materials}

The sample in the present study was REBOCIO from the reserve in Inner Mongolia, China. The main chemical components of this iron ore are provided in Table 1. The iron ore contains low-grade iron of $28.47 \%$ with an an RE oxide content of $6.06 \%$. After ball milling, the particle size of the ore was $90 \mathrm{wt} \%$ below $74 \mu \mathrm{m}$. The mineral composition of the ore was investigated by means of XRD analysis and the result is shown in Fig. 1, which shows that the iron mainly exists in the form of magnetite $\left(\mathrm{Fe}_{3} \mathrm{O}_{4}\right)$ and the main gangue phases are bastnaesite $\left(\mathrm{Ce}\left(\mathrm{CO}_{3}\right) \mathrm{F}\right)$, apatite $\left(\mathrm{Ca}_{5}\left(\mathrm{PO}_{4}\right)_{3} \mathrm{~F}\right)$, fluorite $\left(\mathrm{CaF}_{2}\right)$ and silicon dioxide $\left(\mathrm{SiO}_{2}\right)$. The microstructure of REBOCIO together with energy-dispersive spectrum (EDS) profiles is shown in Fig. 2, which was consistent with the result of XRD analysis (Fig. 1). Pulverized anthracite coal was used as reducer and carburizer and its chemical composition is listed in Table 2, which indicated that the coal was high in fixed carbon, low in ash volatile, sulfur and phosphorus. The reactiveness of the pulverized coal was assessed by chemical reaction ability between pulverized coal and carbon dioxide $(30 \mathrm{~mL} / \mathrm{min})$ through thermogravimetric. It can be seen from Fig. 3 that maximum reaction rate occurred at about $1145^{\circ} \mathrm{C}$.

\subsection{Experimental Apparatus and Procedures}

The experiment, entailed fabricating carbon bearing pel-

Table 1. Chemical composition of REBOCIO (wt \%).

\begin{tabular}{cccccccccc}
\hline $\mathrm{TFe}$ & $\mathrm{FeO}$ & $\mathrm{Fe}_{2} \mathrm{O}_{3}$ & $\mathrm{RE}_{2} \mathrm{O}_{3}$ & $\mathrm{CaF}_{2}$ & $\mathrm{CaO}$ & $\mathrm{MgO}$ & $\mathrm{SiO}_{2}$ & $\mathrm{~S}$ & $\mathrm{P}$ \\
\hline 28.47 & 11.00 & 27.50 & 6.06 & 16.71 & 13.41 & 2.90 & 11.94 & 1.68 & 0.85
\end{tabular}

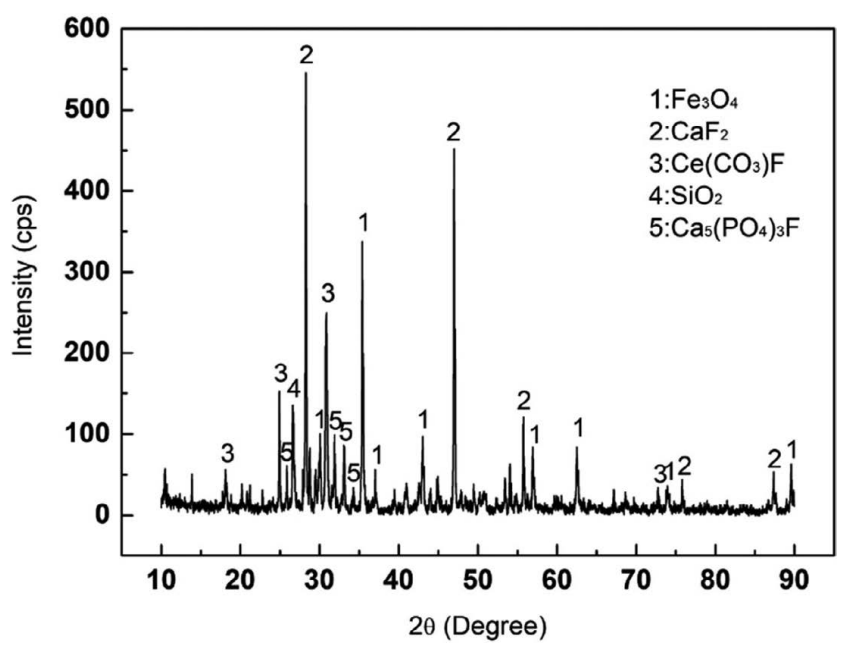

Fig. 1. XRD pattern of REBOCIO. lets consisting of REBOCIO and pulverized coal with mole ratios of "fixed carbon" in the coal to "reducible oxygen" in the iron oxide $(\mathrm{C} / \mathrm{O})$ of $0.8,1.0$, and 1.2. After it was rigorously stirred for approximately $30 \mathrm{~min}$, the prepared mixture was pressed into a cylinder of $2 \mathrm{~cm}$ in diameter and $1.3 \mathrm{~cm}$ in the height and were dried at $105^{\circ} \mathrm{C}$ for $12 \mathrm{~h}$.

The experimental apparatus for reduction is presented schematically in Fig. 4. The apparatus comprises a $\mathrm{MoSi}_{2}$ resistance furnace, which was used to heat a corundum tube. After stabilization of the temperature, the pellets were placed in an alumina crucible hung on an iron wire, and then, the crucible was inserted into the furnace. The dry green composite pellets were heated at temperatures of $1000^{\circ} \mathrm{C}, 1100^{\circ} \mathrm{C}, 1200^{\circ} \mathrm{C}$ and $1250^{\circ} \mathrm{C}$ for a certain time under a high purity $\mathrm{N}_{2}$ flow of $5 \mathrm{~L} / \mathrm{min}$. Once the experiments finished, the samples were taken out rapidly and cooled to room temperature under the protection of nitrogen. Some of the reduced pellets were ground for subsequent analysis and the remainder were mounted in epoxy resin, polished, and examined by SEM-EDS. The phase evaluation during the reduction process was characterized by XRD.

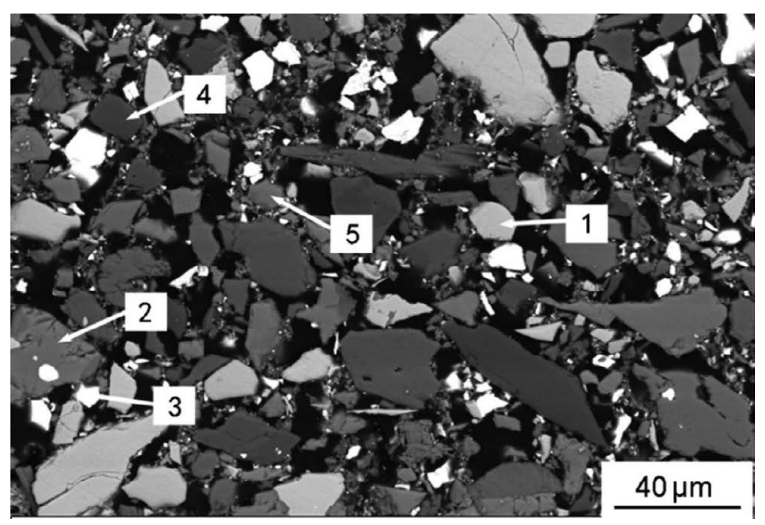

Fig. 2. SEM-EDS analysis of REBOCIO. 1: magnetite $\left(\mathrm{Fe}_{3} \mathrm{O}_{4}\right), 2$ : fluorite $\left(\mathrm{CaF}_{2}\right)$, 3: bastnaesite $\left(\mathrm{Ce}\left(\mathrm{CO}_{3}\right) \mathrm{F}\right)$, 4: silicon dioxide $\left(\mathrm{SiO}_{2}\right)$, 5: apatite $\left(\mathrm{Ca}_{5}\left(\mathrm{PO}_{4}\right)_{3} \mathrm{~F}\right)$.

Table 2. Chemical analysis of the anthracite coal (wt\%).

\begin{tabular}{|c|c|c|c|c|c|c|c|c|c|c|}
\hline \multicolumn{4}{|c|}{ Proximate analysis } & \multicolumn{5}{|c|}{ Ash analysis } & \multirow{2}{*}{$\mathrm{S}$} & \multirow{2}{*}{$P$} \\
\hline $\mathrm{FCd}$ & $\mathrm{Vd}$ & Ad & Mad & $\mathrm{SiO}_{2}$ & $\mathrm{Al}_{2} \mathrm{O}_{3}$ & $\mathrm{Fe}_{2} \mathrm{O}_{3}$ & $\mathrm{CaO}$ & $\mathrm{MgO}$ & & \\
\hline 81.05 & 5.98 & 10.14 & 2.83 & 42.79 & 35.70 & 2.82 & 7.89 & 0.92 & 0.32 & 0.06 \\
\hline
\end{tabular}

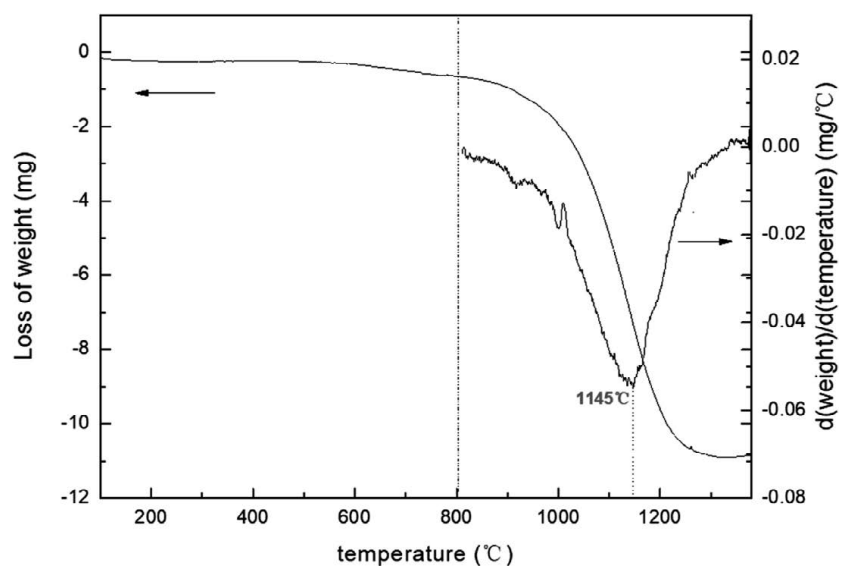

Fig. 3. Reactiveness thermogravimetric curve of anthracite coal. 


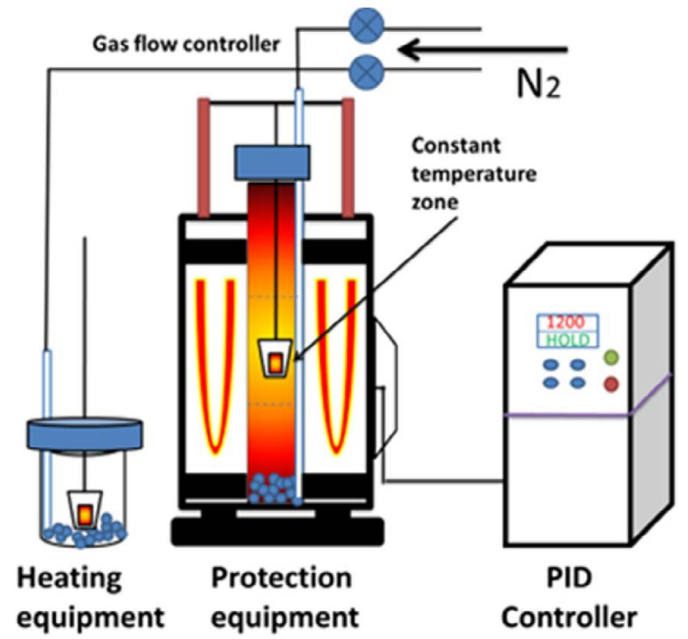

Fig. 4. Schematic diagram of the $\mathrm{MoSi}_{2}$ resistance furnace. (Online version in color.)

The metallization rate of iron components $(\eta \mathrm{Fe})$ determined by chemical analysis can be expressed as Eq. (1):

$$
\eta \mathrm{Fe}=\mathrm{MFe} / \mathrm{TFe} \times 100 \%
$$

MFe: mass content of metallic iron in the reduced pellets, wt $\%$; TFe: mass content of total iron in the reduced pellets, $\mathrm{wt} \%$.

The melting separation experiments were carried out in a muffle furnace. Heat up the furnace to the target temperature of $1400^{\circ} \mathrm{C}$, and then put the graphite tray into the furnace for preheating. When the temperature stabilized, put the pellets on the graphite tray and react in the furnace for 12 min. After melting separation, the samples were then cooled following one of three procedures including water quenching, air cooling, and furnace cooling. For water quenching, the liquid slag was taken out of the furnace and quickly poured into the water, and the generated slag granules were collected at the bottom of the water tank. For air cooling, the graphite tray for holding the slag was promptly removed from the furnace and cooled to ambient temperature. For furnace cooling, the remelted slag was left in the graphite tray to cool to room temperature in the furnace at a cooling rate of $1^{\circ} \mathrm{C} / \mathrm{min}$.

\section{Results and Discussion}

\subsection{Isothermal Reduction Behavior}

The effect of temperature and time on the reduction behavior of composite pellets was studied at a $\mathrm{C} / \mathrm{O}$ ratio of 1.2, and the results are shown in Fig. 5. These results show that the temperature and heating time have a significant effect on the metallization degree of composite pellets. The reduction rate was improved by increasing the temperature from 1000 to $1250^{\circ} \mathrm{C}$ at the same heating time. The metallization rate of the pellet was high as $91 \%$ at $1250^{\circ} \mathrm{C}$ for a heating duration of $9 \mathrm{~min}$, but it was only approximately $65 \%$ at the final reduction point at $1000^{\circ} \mathrm{C}$. It can also be seen that the time required to reach the end point of the reduction reaction above $1200^{\circ} \mathrm{C}$ was much less than that required below $1100^{\circ} \mathrm{C}$. The above results suggest that in the reduction of pellets below $1100^{\circ} \mathrm{C}$, the energy provided is inadequate to bring about appreciable reduction. How-

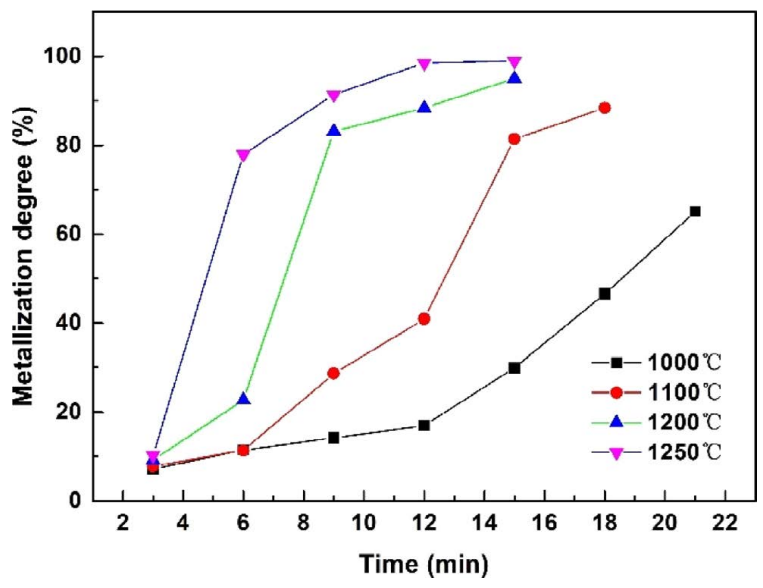

Fig. 5. Effects of temperature and heating time on the metallization degree of pellets. (Online version in color.)

ever, significant reduction occurs above $1100^{\circ} \mathrm{C}$, which is in agreement with the earlier researchers. ${ }^{18)}$ This performance was largely attributed to the increase of reactivity of pulverized coal with the increase of temperature. With the increase of temperature, the gasification rate of anthracite increases, and the generated $\mathrm{CO}$ directly participates in the reduction process of iron oxide into metallic iron, thus promoting the reduction of pellet ore). At the same time, compared with the results of Chen et al., ${ }^{19)}$ under the experimental conditions, the rare earth iron ore obtained a higher metallization rate under the condition of relatively lower than $1200^{\circ} \mathrm{C}$. This can be attributed to the obvious promotion of rare earth elements on the reduction of iron oxides. ${ }^{20)}$ Although impurities such as calcium fluoride $\left(\mathrm{CaF}_{2}\right)$ and magnesium oxide $(\mathrm{MgO})$ have barrier effect on iron oxide reduction, ${ }^{21)}$ the final result of comprehensive effect shows that they can promote iron oxide reduction. As shown in Fig. 3, in the non-isothermal reactivity experiment with the anthracite coal, the reaction rate of the coal increased as the temperature increased at temperatures below $1145^{\circ} \mathrm{C}$, after which the rate decreased because of the consumption of the coal. This showed that the reaction temperature should at least be higher than $1145^{\circ} \mathrm{C}$ to achieve the maximum gasification rate, which is in agreement with the results of the reduction experiment. Thus, the reduction temperature should be approximately $1200^{\circ} \mathrm{C}$ to achieve a higher metallization rate.

The effect of the $\mathrm{C} / \mathrm{O}$ ratio on the metallization degree of the pellets was studied at $1200^{\circ} \mathrm{C}$. Based on the theoretical calculation, the values of $\mathrm{C} / \mathrm{O}$ ratios were chosen as $0.8,1.0$, and 1.2. The reduction curves are plotted in Fig. 6 and show that the metallization degree tends to increase as the $\mathrm{C} / \mathrm{O}$ ratio increases. In the early stage of the reaction, the $\mathrm{C} / \mathrm{O}$ ratio has little influence on the degree of metallization. In addition, the metallization rates of pellets with different $\mathrm{C} / \mathrm{O}$ ratios were all as low as approximately $20 \%$ when the heating time was $6 \mathrm{~min}$. That is because heat transfer controls the reaction in the relatively large pellet at the early stage of the reaction, and the $\mathrm{CO}$ partial pressure is relatively low for the direct reduction to produce $\mathrm{CO}$, which is the main reaction during this time. ${ }^{22)}$ However, during the later stage of the reaction, the metallization degree of the pellets with a low $\mathrm{C} / \mathrm{O}$ ratio was obviously lower, owing to low $\mathrm{CO}$ partial pressure, which was more obvious for the pellets with a low 


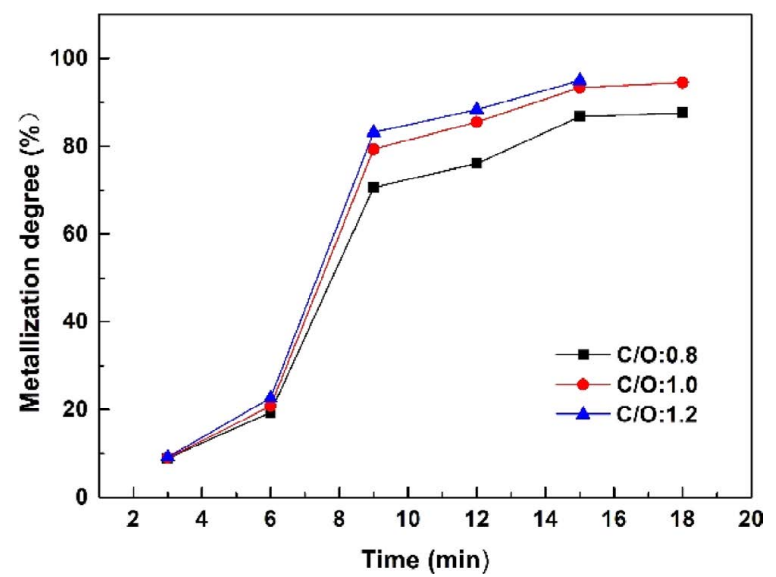

Fig. 6. Effects of $\mathrm{C} / \mathrm{O}$ ratio on the metallization degree of pellets at $1200^{\circ} \mathrm{C}$. (Online version in color.)

$\mathrm{C} / \mathrm{O}$ ratio. When the reaction time is 15 minutes, the metallization rate of pellets increases obviously as the $\mathrm{C} / \mathrm{O}$ ratio increases from 0.8 to 1.0 , but when $\mathrm{C} / \mathrm{O}$ ratio increases from 1.0 to 1.2 , the metallization rate almost remains unchanged. This is due to the change of carbon content from unsaturated $\left(\mathrm{n}_{\mathrm{c}}: \mathrm{n}_{\mathrm{o}}<1\right)$ to saturated $\left(\mathrm{n}_{\mathrm{c}}: \mathrm{n}_{\mathrm{o}}=1\right)$. The results of this experiment indicate that $\mathrm{C} / \mathrm{O}$ ratio of 1.0 is appropriate to achieve a higher metallization rate.

\subsection{Phase Transformation and Microscopic Examina- tion for the Carbon Bearing Pellets}

The mechanism of the reduction process was clarified by using XRD to analyze the powder samples of the pellets that were reduced for different heating times. The results are shown in Fig. 7. The experiments were performed at $1100^{\circ} \mathrm{C}$ at the intervals of $3 \mathrm{~min}$. Before reduction, the main phases in the pellet were magnetite, bastnaesite, silicon dioxide and fluorite. A small amount of hematite, which also existed in the pellet before the reaction, disappeared at $6 \mathrm{~min}$. The intensity of $\mathrm{Fe}_{3} \mathrm{O}_{4}$ peaks decreased as the reduction progressed and the peaks disappeared at 9 min. The characteristic peak of wüstite $(\mathrm{FeO})$ came into being at 6 min and these of metallic iron $(\mathrm{Fe})$ appeared at 9 min. Because the reduction of iron oxides can be divided into three steps, $\mathrm{Fe}_{2} \mathrm{O}_{3}-\mathrm{Fe}_{3} \mathrm{O}_{4}, \mathrm{Fe}_{3} \mathrm{O}_{4}-\mathrm{FeO}$ and $\mathrm{FeO}-\mathrm{Fe}$ in order at the temperature above $570^{\circ} \mathrm{C}^{23)}$ The intensity of the $\mathrm{Ce}\left(\mathrm{CO}_{3}\right) \mathrm{F}$ peaks disappeared at $3 \mathrm{~min}$, after which the peaks of $\mathrm{SiO}_{2}$ disappeared and those of RE phases $\left(\mathrm{Ca}_{3} \mathrm{Ce}_{2}\right.$ $\left[(\mathrm{Si}, \mathrm{P}) \mathrm{O}_{4}\right]_{3} \mathrm{~F}$ and $\left.\mathrm{Ce}_{4.67}\left(\mathrm{Si} \mathrm{O}_{4}\right)_{3} \mathrm{O}\right)$ appeared when the pellet was reduced for $6 \mathrm{~min}$. After $15 \mathrm{~min}$, the peaks of the RE phase continued to intensify without any new phase occurring. This shows that slag-forming reaction takes place when the iron oxide is reduced during the heating process. Two kinds of rare earth phases came into being in the slagforming reaction. As for the generation of $\mathrm{Ce}_{4.67}\left(\mathrm{Si} \mathrm{O}_{4}\right)_{3} \mathrm{O}$, The reaction can be expressed by Eqs. (2) and (3): ${ }^{24)}$

$$
\begin{gathered}
\mathrm{Ce}\left(\mathrm{CO}_{3}\right) \mathrm{F} \Rightarrow \mathrm{CeOF}+\mathrm{CO}_{2} \uparrow \ldots \ldots . . \\
\mathrm{CeOF}+\mathrm{SiO}_{2}+\mathrm{O} \Rightarrow \mathrm{Ce}_{4.67}\left(\mathrm{SiO}_{4}\right)_{3}+\mathrm{F}
\end{gathered}
$$

$\mathrm{Ce}\left(\mathrm{CO}_{3}\right) \mathrm{F}$ can be decomposed into $\mathrm{CeOF}$ and $\mathrm{CO}_{2}$ easily in Eq. (2) at $650^{\circ} \mathrm{C}$, which accounts for the disappearance of the $\mathrm{Ce}\left(\mathrm{CO}_{3}\right) \mathrm{F}$ peaks during the early stage of the reaction, as shown in Fig. 7. The reaction in Eq. (3) is easy to carry

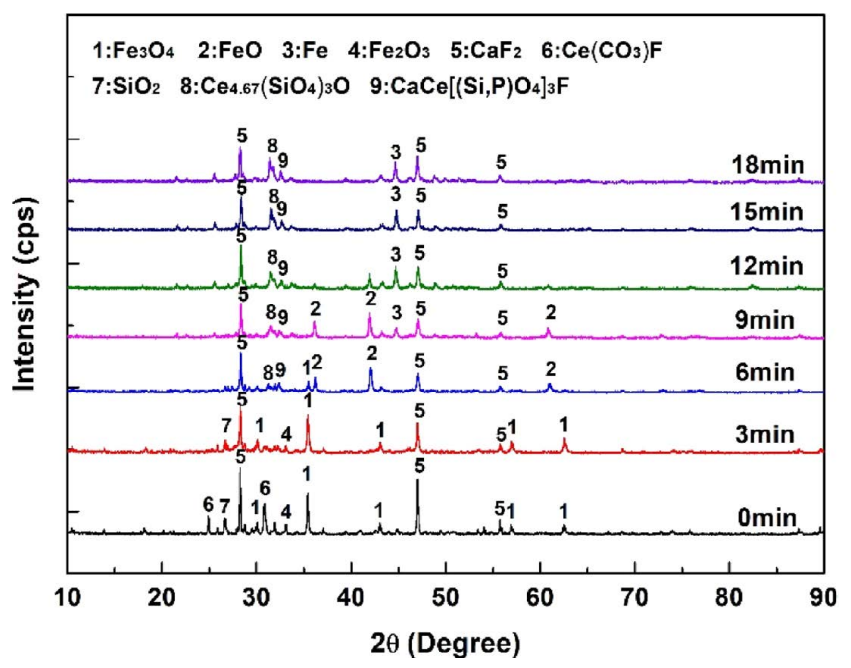

Fig. 7. XRD patterns of pellets during reduction process at $1100^{\circ} \mathrm{C}$. (Online version in color.)

out because the grain size of the ER phase is small and the ore contains sufficient $\mathrm{SiO}_{2}$. The raw material was pressed into a compact cylinder, which promoted the reaction by strengthening the solid-solid contact. As for the generation of $\mathrm{Ca}_{3} \mathrm{Ce}_{2}\left[(\mathrm{Si}, \mathrm{P}) \mathrm{O}_{4}\right]_{3} \mathrm{~F}$, it can be produced by isomorphism replacement of $\mathrm{Ca}_{5}\left(\mathrm{PO}_{4}\right)_{3} \mathrm{~F}$. Apatite is the most widespread calcium phosphate mineral, and its crystal structure can be replaced by a wide range of isomorphisms. ${ }^{25-28)}$ The replacement of $\mathrm{PO}_{4}{ }^{3-}$ by $\mathrm{SiO}_{4}{ }^{2-}$ is coupled because of the difference in their valence states, and one of the most common replacement mechanisms is reaction in Eq. (4): ${ }^{.9)}$

$$
\mathrm{SiO}_{4}^{4-}+\mathrm{REE}^{3+} \equiv \mathrm{Ca}^{2+}+\mathrm{PO}_{4}^{3-}
$$

In this process, the $\mathrm{PO}_{4}{ }^{3-}$ tetrahedron is replaced by the $\mathrm{SiO}_{4}{ }^{4-}$ tetrahedron and $\mathrm{Ca}^{2+}$ is replaced by $\mathrm{REE}^{3+}$ to produce $\mathrm{Ca}_{3} \mathrm{Ce}_{2}\left[(\mathrm{Si}, \mathrm{P}) \mathrm{O}_{4}\right]_{3} \mathrm{~F}$. The reaction continued as the heating time was prolonged, which is consistent with the XRD results.

Figure 8 presents the morphological changes in a pellet reduced at $1100^{\circ} \mathrm{C}$ for different reaction times, as observed with SEM. The microstructure of the pellet reduced for 3 min was almost the same as that of the original ore, except that the composite pellet contained some pulverized coal. When the reaction lasts for 6 minutes, the coal particles become smaller, forming some fine metallic iron particles and pores. The pore formation of pellets is conducive to gas diffusion and promotes indirect reduction. The reduction clearly caused a layer that cover the surface of the coal at 9 min. This made direct reduction difficult because the iron oxide was no longer in contact with the coal. The indirect reaction is dominant, and the rate of reaction is controlled by the carbon solution loss reaction and gas diffusion. The pores are also further shrunk, making it difficult to find them when the reaction time reaches 12 minutes. As time proceeded, much more metallic iron was observed and the iron particles increased in size. When reduced for $18 \mathrm{~min}$, the reduced iron existed in the form of a sponge because of the consumption of pulverized coal in the process of reduction.

\subsection{Characteristics of the Rare Earth Slag under Dif- ferent Cooling Conditions}

Pellets with a $\mathrm{C} / \mathrm{O}$ ratio of 1.0 were melted until separa- 
tion in the muffle furnace at $1400^{\circ} \mathrm{C}$ for $12 \mathrm{~min}$. After the slag and iron are melted and separated, the slag was removed and allowed to cool in the air. The chemical composition of the air-cooling slag is provided in Table 3. The slag, with a $\mathrm{RE}_{2} \mathrm{O}_{3}$ content of $10.03 \%$, is a good raw material for extracting REEs. The XRD pattern and SEM micrographs of RE-rich slag are shown in Figs. 9 and 10(a), respectively. The XRD pattern shows that the main slag-phases in the slag are cuspidine $\left(\mathrm{Ca}_{4} \mathrm{Si}_{2} \mathrm{O}_{7} \mathrm{~F}_{2}\right)$ and fluorite $\left(\mathrm{CaF}_{2}\right)$, which is in good accordance with the microscopic morphology detected by SEM. However, the structure of the RE phase found by XRD did not correspond to that on any PDF card, thus, the material structure of the RE phase could not be distinguished (further research is presented in the next section). As shown in the SEM micrographs, the REEs were centralized in the RE-containing phases. However, owing to the cooling rate of air-cooled slag is relatively fast, the size of crystals in the RE phases is approximately $25 \mu \mathrm{m}$, which is relatively small. Furthermore, the strip-shape crystalline phase shows that the crystal development of the RE phases is incomplete. The fluorite phase is mostly elliptic with an approximate size is of $10 \mu \mathrm{m}$. EDS indicated that the matrix phase is cuspidine.

From the aspects of crystallography, the RE phase can be further grown and enriched by holding temperature and slow cooling. ${ }^{14)}$ This was verified, by studying the slag cooled with furnace. The SEM micrographs of RE-rich slag, which are shown in Fig. 10(b). It shows that the average size of $\mathrm{RE}$ phase in the slag cooled in the furnace is approximately
$120 \mu \mathrm{m}$ wide, which is much larger than that in air cooling slag. The RE-containing phase in slag cooled in the furnace has a more well-defined structure, which is a hexagonal crystalline system. This is because this slag has more time to crystallize because of the slow cooling rate, which is conducive to mass transfer. This finding is indicative of need to hold temperature or slow cooling rate for further growth

Table 3. Chemical composition of rare-earth-rich slag (wt\%)

\begin{tabular}{ccccccc}
\hline $\mathrm{CaF}_{2}$ & $\mathrm{Re}_{2} \mathrm{O}_{3}$ & $\mathrm{CaO}$ & $\mathrm{SiO}_{2}$ & $\mathrm{P}_{2} \mathrm{O}_{5}$ & $\mathrm{FeO}$ & $\mathrm{S}$ \\
\hline 21.98 & 10.03 & 17.82 & 16.52 & 3.21 & 6.27 & 0.62 \\
\hline
\end{tabular}

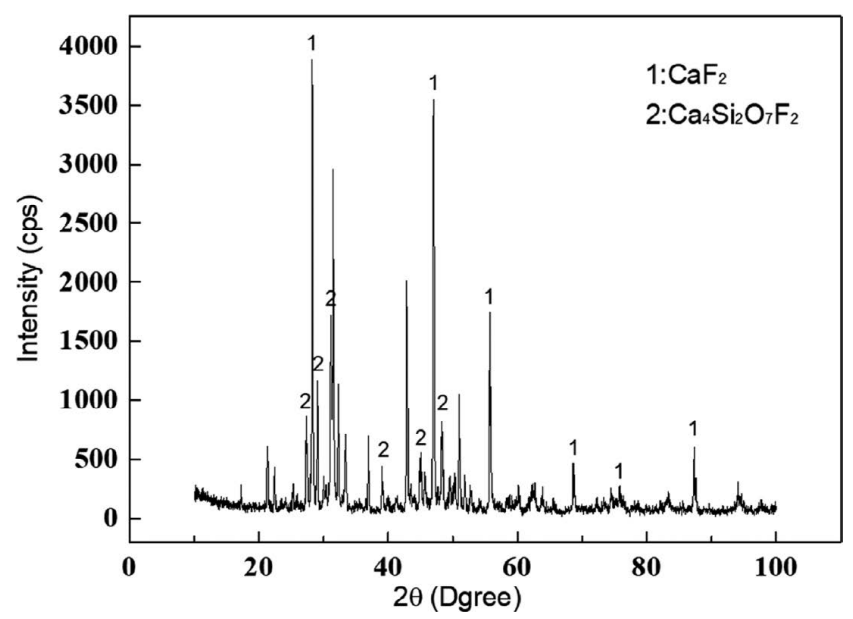

Fig. 9. XRD pattern of RE-rich slag.
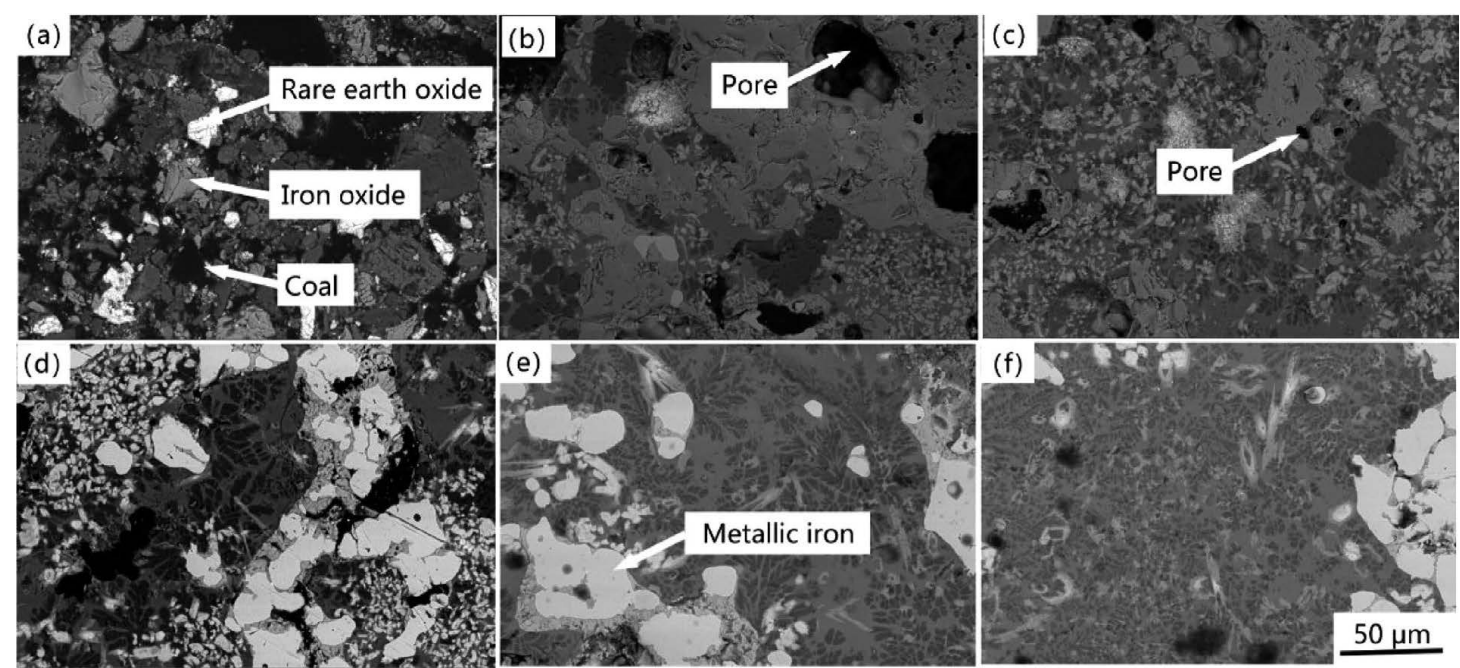

Fig. 8. Microstructure of the pellets during reduction at (a) $3 \mathrm{~min}$, (b) $6 \mathrm{~min}$, (c) $9 \mathrm{~min}$, (d) $12 \mathrm{~min}$, (e) $15 \mathrm{~min}$, (f) $18 \mathrm{~min}$.

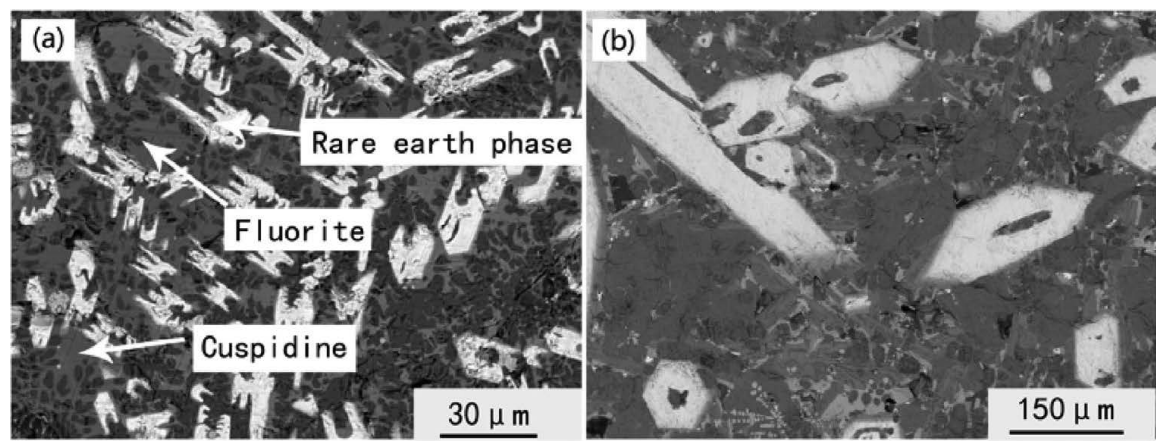

Fig. 10. SEM micrograph of the RE-rich slag: (a) air cooled slag, (b) furnace cooled slag. 
and enrichment of RE phase.

An area scan was carried out by electron probe microanalysis (EPMA) to determine the elemental distribution of RE-containing phase in the slag cooled in the furnace, and the result is show in Fig. 11. The REEs are shown to be mainly concentrated in the RE-containing phase, which also contained silicon and calcium. It is worth mentioning that only a small amount of the element $\mathrm{P}$ existed in the REcontaining phase, and most of the $\mathrm{P}$ was concentrated at the junction of the RE-containing phase and the matrix phase. In order to understand the structure and composition of RE phases, the RE phases in slag were studied experimentally in the next section.

\subsection{X-ray Crystallography}

The composition of RE phase in the slag after direct reduction and melting is still controversial. For example, $\mathrm{Li}$ et al. $^{16)}$ believed that it is $\mathrm{RE}_{2} \mathrm{O}_{3}-\mathrm{CaO}-\mathrm{SiO}_{2}$, whereas $\mathrm{Li}$ et al. ${ }^{17)}$ to be $\mathrm{Ca}_{3} \mathrm{Ce}_{2}\left[(\mathrm{Si}, \mathrm{P}) \mathrm{O}_{4}\right]_{3} \mathrm{~F}$. The disagreement could largely be attributed to the fact that they used XRD to characterize the RE phases, and that the XRD pattern of these phases on the PDF cards was incomplete. This prompted us to use single-crystal XRD to further study the structure of the RE-containing phase.

The main crystalline phase does not change when the cooling rate is changed. ${ }^{14)}$ Thus, the furnace slag was used for the single-crystal analysis. The oxides of RE phase are listed in Table 4.

For Single-crystal XRD studies, the sample was ground in an agate mortar and dispersed in a small volume $(1 \mathrm{~mL})$ of ethanol. The suspension was dropped onto the glass of a binocular microscope, and placed in a desiccator before selecting a high-quality phase crystal particle from the RE

Table 4. Results of the electron microprobe analysis of the rare earth phase.

\begin{tabular}{lrrrrrrrr}
\hline & $\mathrm{La}_{2} \mathrm{O}_{3}$ & $\mathrm{Ce}_{2} \mathrm{O}_{3}$ & $\mathrm{Nd}_{2} \mathrm{O}_{3}$ & $\mathrm{SiO}_{2}$ & $\mathrm{P}_{2} \mathrm{O}_{5}$ & $\mathrm{SO}_{3}$ & $\mathrm{CaO}$ & $\mathrm{F}$ \\
\hline $\mathrm{Mass} \%$ & 12.15 & 32.02 & 10.42 & 24.92 & 2.99 & 0.51 & 14.42 & 2.57 \\
$\mathrm{Mol} \%$ & 3.73 & 9.75 & 3.1 & 41.46 & 2.11 & 0.64 & 25.7 & 13.52 \\
\hline
\end{tabular}

phase. The crystal structure was characterized using Bruker (D8 VENTURE) single-crystal XRD data collected from a high-quality crystal particle. The structure was solved and refined using the SHELXTL Software Package ${ }^{30)}$ with reference to the EPMA results of the RE phases (Table 4). The crystal structure is a hexagonal system with space group $P 63 / \mathrm{m}$ and unitcell parameters $\mathrm{a}=9.5908(3) \AA$, $\mathrm{b}=9.5908(3) \AA, \mathrm{c}=7.0268(2) \AA, \beta=90(3)^{\circ}$, and $V=$ 559.75(4) $\AA 3$ with the formula is $\mathrm{Ca}_{4.14} \mathrm{Ce}_{4.12} \mathrm{La}_{1.74} \mathrm{Si}_{6} \mathrm{O}_{24} \mathrm{~F}_{2}$. Details of the data collection and refinement are given in

Table 5. The atom coordinates and displacement parameters

Table 5. Crystal data, data collection information, and refinement details for the RE phase.

\begin{tabular}{|c|c|}
\hline Crystal data & \\
\hline Formula & $\mathrm{Ca}_{4.14} \mathrm{Ce}_{4.12} \mathrm{La}_{1.74} \mathrm{Si}_{6} \mathrm{O}_{24} \mathrm{~F}_{2}$ \\
\hline Formula weight & 1575.51 \\
\hline Space group, z & $\mathrm{P} 63 / \mathrm{m}, 1$ \\
\hline $\mathrm{a}, \mathrm{b}, \mathrm{c}(\AA)$ & $9.5908(3), 9.5908(3), 7.0268(2)$ \\
\hline $\mathrm{F}(000), \rho_{\text {calc }}\left(\mathrm{g} \cdot \mathrm{cm}^{-3}\right)$ & 715.0 \\
\hline $\mathrm{M} \mu\left(\mathrm{mm}^{-1}\right)$ & 12.848 \\
\hline Absorption correction & Multi-scan \\
\hline Crystal dimensions (mm) & $0.102 \times 0.083 \times 0.065 \mathrm{~mm}$ \\
\hline \multicolumn{2}{|l|}{ Data collection and refinement } \\
\hline Diffractometer & Photon II system \\
\hline$\lambda(\mathrm{Mo}-\mathrm{K} \alpha)(\AA), \mathrm{T}(\mathrm{K})$ & $0.71073,293$ \\
\hline Crystal-detector distance (mm) & 50 \\
\hline $\mathrm{h}, \mathrm{k}, 1$ ranges & $-12 \rightarrow 12,-12 \rightarrow 12,-9 \rightarrow 9$ \\
\hline Total reflections measured & 8183 \\
\hline Unique reflections & $483\left(R_{\text {int }}=0.0264\right)$ \\
\hline Refinement on & $\mathrm{F} 2$ \\
\hline $\mathrm{R} 1(\mathrm{~F}), \mathrm{wR} 2_{\mathrm{all}}\left(\mathrm{F}^{2}\right)^{\mathrm{a}}$ & $0.0208,0.0519$ \\
\hline “Observed” refls & $482\left[\mathrm{~F}_{0}>4 \sigma\left(\mathrm{F}_{0}\right)\right]$ \\
\hline No. of refined parameters & 46 \\
\hline GooF & 1.207 \\
\hline$\Delta \rho_{\min }, \Delta \rho_{\max }\left(\mathrm{e} / \AA^{3}\right)$ & $-0.56,0.84$ \\
\hline
\end{tabular}
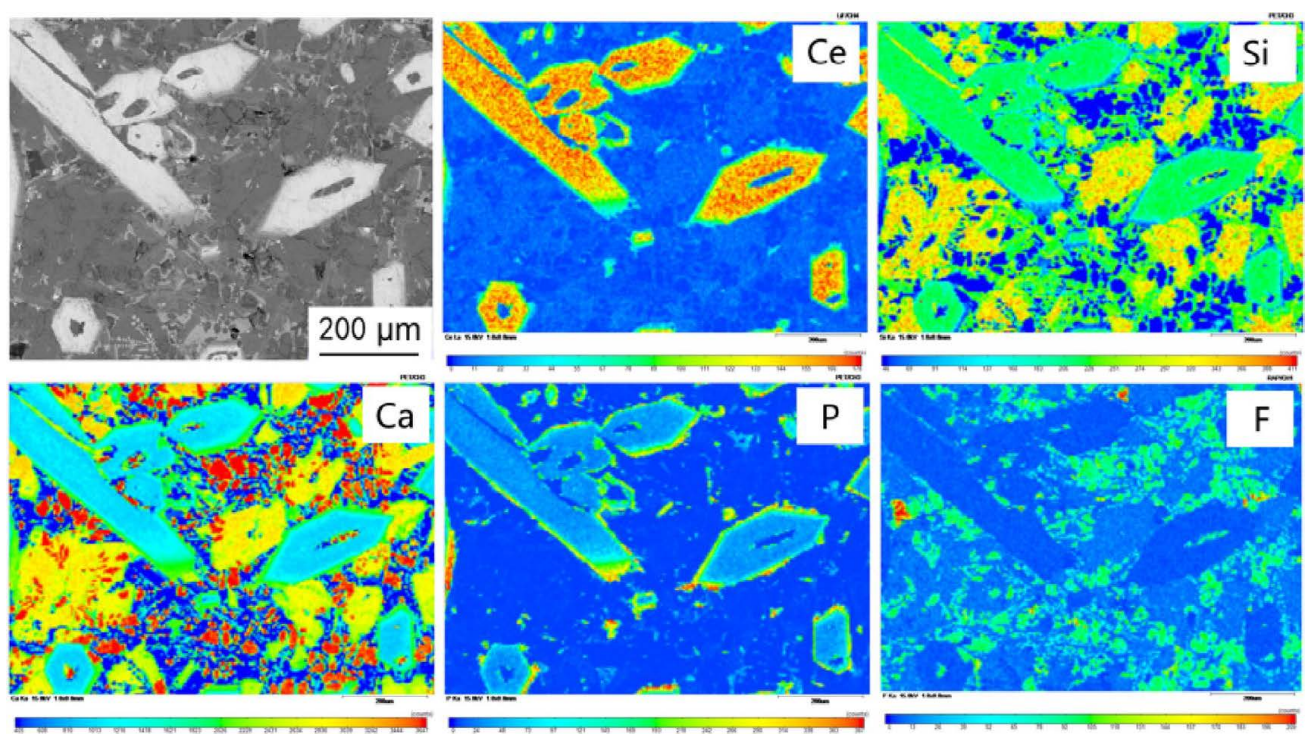

Fig. 11. Mineralogy and distribution of main elements of furnace-cooled slag. (Online version in color.) 
are shown in Tables 6 and 7, respectively. Table 8 contains the bond angles. Figure 12 shows the atomic structure and unit cell of the RE-enriched phase $\mathrm{Ca}_{4.14} \mathrm{Ce}_{4.12} \mathrm{La}_{1.74} \mathrm{Si}_{6} \mathrm{O}_{24} \mathrm{~F}_{2}$.

After analytical analysis and refinement, the $\mathrm{R} 1=0.0203$, which is a good value. Under the conditions employed in this study, the $\mathrm{RE}_{2} \mathrm{O}_{3}$ was enriched to $\mathrm{Ca}_{4.14} \mathrm{Ce}_{4.12} \mathrm{La}_{1.74} \mathrm{Si}_{6} \mathrm{O}_{24} \mathrm{~F}_{2}$. REEs are known to have valence of +3 , which can also be verified by thermodynamic calculation. Considering that the reducing agent in this smelting process is carbon, and the gas phase is mainly composed of $\mathrm{CO}$, $\mathrm{Ce}$ has valence of +3 and +4 . The thermodynamic data obtained by using Factsage software are as follows:

$2 \mathrm{CeO}_{2}+\mathrm{C}=\mathrm{Ce}_{2} \mathrm{O}_{3}+\mathrm{CO}, \Delta \mathrm{G}^{\circ}=259910-221.6 \mathrm{~T}(\mathrm{~J}) .$.

Under the smelting conditions of $\mathrm{T}=1400^{\circ} \mathrm{C}$ and $\mathrm{P}_{\mathrm{CO}}=$ $101325 \mathrm{~Pa}$, formula (5) can be obtained as follows: $\Delta \mathrm{G}=$ $-110826.8 \mathrm{~J}<<0$. The calculation results show that the + 4 valence state of $\mathrm{Ce}$ is unstable in slag and that Ce exists in the +3 valence state. This is consistent with the analytical result.

In addition, according to the analytical results, the positions of $\mathrm{Ce}$, $\mathrm{La}$, and $\mathrm{Ca}$ can be occupied by any of these elements. Further, because $\mathrm{Si}$ exists in the form of $\mathrm{SiO}_{4}{ }^{4-}$, the

Table 6. Atomic coordinates and equivalent isotropic atomic displacement parameters $\left(\AA^{2}\right)$ for the RE phase.

\begin{tabular}{ccccc}
\hline atom & $\mathrm{x}$ & $\mathrm{y}$ & $\mathrm{z}$ & $\mathrm{Ueq}$ \\
\hline $\mathrm{C} 1$ & $0.75792(4)$ & $0.74622(4)$ & 0.75 & $0.00734(17)$ \\
$\mathrm{Ca} 1$ & $0.75792(4)$ & $0.74622(4)$ & 0.75 & $0.00734(17)$ \\
$\mathrm{La} 1$ & $0.75792(4)$ & $0.74622(4)$ & 0.75 & $0.00734(17)$ \\
$\mathrm{S} 11$ & $0,02827(16)$ & $0.62943(15)$ & 0.75 & $0.0052(4)$ \\
$\mathrm{F} 1$ & 1.00 & 1.00 & 0.75 & $0.047(3)$ \\
O1 & $0.1252(5)$ & $0.5322(5)$ & 0.75 & $0.0195(10)$ \\
$\mathrm{La} 2$ & 0.666667 & 0.333333 & $0.49787(8)$ & $0.0078(2)$ \\
$\mathrm{Ca} 2$ & 0.666667 & 0.333333 & $0.49787(8)$ & $0.0078(2)$ \\
$\mathrm{C} 2$ & 0.666667 & 0.333333 & $0.49787(8)$ & $0.0078(2)$ \\
O2 & $0.0883(4)$ & $0.7475(4)$ & $0.9335(5)$ & $0.0302(9)$ \\
O3 & $0.8353(4)$ & $0.5118(5)$ & 0.75 & $0.0140(8)$ \\
\hline
\end{tabular}

Table 7. Anisotropic atomic displacement parameters $\left(\AA^{2}\right)$ for RE phase.

\begin{tabular}{ccccccc}
\hline Atom & $\mathrm{U} 11$ & $\mathrm{U} 22$ & $\mathrm{U} 33$ & $\mathrm{U} 23$ & $\mathrm{U} 13$ & $\mathrm{U} 12$ \\
\hline $\mathrm{Ce} 1$ & $0.0108(2)$ & $0.0081(2)$ & $0.0053(2)$ & 0 & 0 & $0.00641(15)$ \\
$\mathrm{Ca} 1$ & $0.0108(2)$ & $0.0081(2)$ & $0.0053(2)$ & 0 & 0 & $0.00641(15)$ \\
$\mathrm{La} 1$ & $0.0108(2)$ & $0.0081(2)$ & $0.0053(2)$ & 0 & 0 & $0.00641(15)$ \\
$\mathrm{Si}$ & $0.0038(6)$ & $0.0050(6)$ & $0.0054(6)$ & 0 & 0 & $0.0013(5)$ \\
$\mathrm{F} 1$ & $0.023(2)$ & $0.023(2)$ & $0.094(8)$ & 0 & 0 & $0.0115(10)$ \\
$\mathrm{O} 1$ & $0.0140(19)$ & $0.0111(18)$ & $0.036(3)$ & 0 & 0 & $0.0082(15)$ \\
$\mathrm{La} 2$ & $0.0084(2)$ & $0.0084(2)$ & $0.0067(3)$ & 0 & 0 & $0.00419(12)$ \\
$\mathrm{Ca} 2$ & $0.0084(2)$ & $0.0084(2)$ & $0.0067(3)$ & 0 & 0 & $0.00419(12)$ \\
$\mathrm{Ce} 2$ & $0.0084(2)$ & $0.0084(2)$ & $0.0067(3)$ & 0 & 0 & $0.00419(12)$ \\
$\mathrm{O} 2$ & $0.0262(16)$ & $0.0218(15)$ & $0.0153(15)$ & $-0.0108(13)$ & $0.0115(13)$ & $-0.0085(13)$ \\
$\mathrm{O} 3$ & $0.0064(16)$ & $0.0129(18)$ & $0.0135(19)$ & 0 & 0 & $-0.0021(14)$ \\
\hline
\end{tabular}

molecular formula can be written as $(\mathrm{Ca}, \mathrm{Ce}, \mathrm{La})_{5}\left(\mathrm{SiO}_{4}\right)_{6} \mathrm{~F}$.

This result is different from what $\mathrm{Li}$ et al. ${ }^{16)}$ thinks $\mathrm{RE}_{2} \mathrm{O}_{3}-\mathrm{CaO}-\mathrm{SiO}_{2}$ and Ding et al. ${ }^{13)}$ thinks [7(Ca, Ce, La, $\left.\mathrm{Nd})_{2} \cdot \mathrm{SiO}_{4}\right](\mathrm{F}, \mathrm{O})_{10}$ and Li et al. ${ }^{17)}$ thinks $\mathrm{Ca}_{3} \mathrm{Ce}_{2}\left[(\mathrm{Si}, \mathrm{P}) \mathrm{O}_{4}\right]_{3} \mathrm{~F}$. It is worth discussing the above-mentioned RE phase with the formula $\mathrm{REO}_{3}-\mathrm{CaO}-\mathrm{SiO}_{2}$, which does not contain F. Li et $a l .{ }^{16)}$ used EDS to determine the composition of the RE phase. but not detect $F$ in the phase. In our study, we also failed to detect $F$ in the EDS analysis, but later found that the peak of $\mathrm{F}$ overlapped with the peak of Ce, making it difficult to detect F. Therefore, an electron probe was used to examine the RE phase, and the results showed that the molar ratio of $\mathrm{F}$ in this phase accounted for $13.52 \%$. In the process of analyzing the structure, the $\mathrm{R} 1=0.0208$ obtained by adding

Table 8. Bond angles $\left(^{\circ}\right)$ for RE phase.

\begin{tabular}{|c|c|c|c|}
\hline Bond angles & Size & Bond angles & Size \\
\hline $\mathrm{Ce} 1-\mathrm{O} 2 \times 2$ & $2.360(3)$ & Ce1-F1 & $2.3798(4)$ \\
\hline Ce1-O1 & $2.411(4)$ & $\mathrm{Ce} 1-\mathrm{O} 2 \times 2$ & $2.565(3)$ \\
\hline Ce1-O3 & $2.697(4)$ & Ce1-Si1 & $3.1921(13)$ \\
\hline Cel-Si1 & $3.2988(13)$ & Ce1-La2 & $4.0149(4)$ \\
\hline Ce1-La2 & $4.0150(4)$ & Ce1-Ce1 & $4.1220(6)$ \\
\hline $\mathrm{Ca} 1-\mathrm{O} 2 \times 2$ & $2.360(3)$ & Ca1-F1 & $2.3798(4)$ \\
\hline Ca1-O1 & $2.411(4)$ & $\mathrm{Ca} 1-\mathrm{O} 2 \times 2$ & $2.565(3)$ \\
\hline Ca1-O3 & $2.697(4)$ & Ca1-Sil & $3.1921(13)$ \\
\hline Cal-Sil & $3.2988(13)$ & Ca1-Sil & $3.5389(13)$ \\
\hline $\mathrm{Ca} 1-\mathrm{Ca} 2$ & $4.0150(4)$ & Ca1-Ca1 & $4.2436(2)$ \\
\hline La1-O $2 \times 2$ & $2.360(3)$ & La1-F1 & $2.3798(4)$ \\
\hline La1-O1 & $2.411(4)$ & La1-O $2 \times 2$ & $2.565(3)$ \\
\hline La1-O3 & $2.697(4)$ & La1-Si1 & 3.1921(13) \\
\hline La1-Si1 & $3.2988(13)$ & La1-Si1 & $3.5389(13)$ \\
\hline La1-Ce2 & $4.0150(4)$ & Si1-O1 & $1.613(4)$ \\
\hline Si1-O3 & $1.616(4)$ & $\mathrm{Si} 1-\mathrm{O} 2 \times 2$ & $1.620(3)$ \\
\hline Si1-La2 × 2 & $3.2676(11)$ & O1-La $2 \times 2$ & $2.471(3)$ \\
\hline $\mathrm{La} 2-\mathrm{O} 3 \times 2$ & $2.432(2)$ & La2-O3 & $2.432(3)$ \\
\hline $\mathrm{La} 2-\mathrm{O} 2 \times 3$ & $2.855(4)$ & $\mathrm{Ca} 2-\mathrm{O} 3 \times 3$ & $2.432(3)$ \\
\hline $\mathrm{Ca} 2-\mathrm{O} 2 \times 3$ & $2.855(4)$ & $\mathrm{Ce} 2-\mathrm{O} 3 \times 3$ & $2.432(3)$ \\
\hline $\mathrm{Ce} 2-\mathrm{O} 2 \times 3$ & $2.855(4)$ & & \\
\hline
\end{tabular}

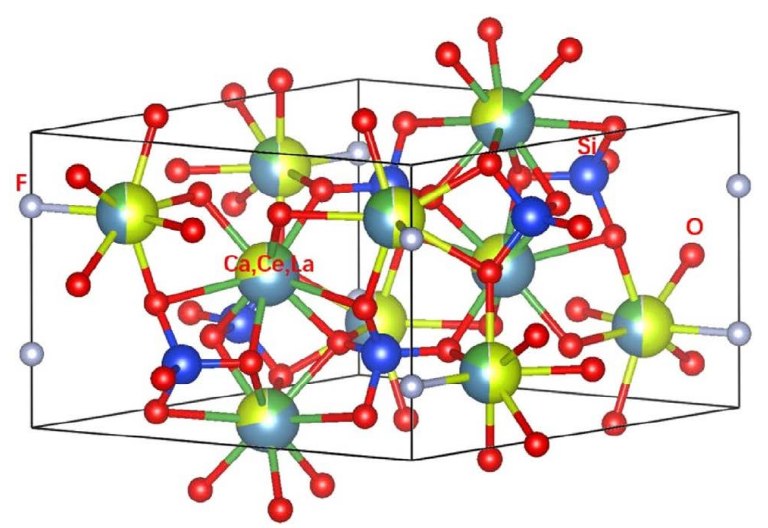

Fig. 12. Structure diagram of $\mathrm{Ca}_{4.14} \mathrm{Ce}_{4.12} \mathrm{La}_{1.74} \mathrm{Si}_{6} \mathrm{O}_{24} \mathrm{~F}_{2}$. (Online version in color.) 


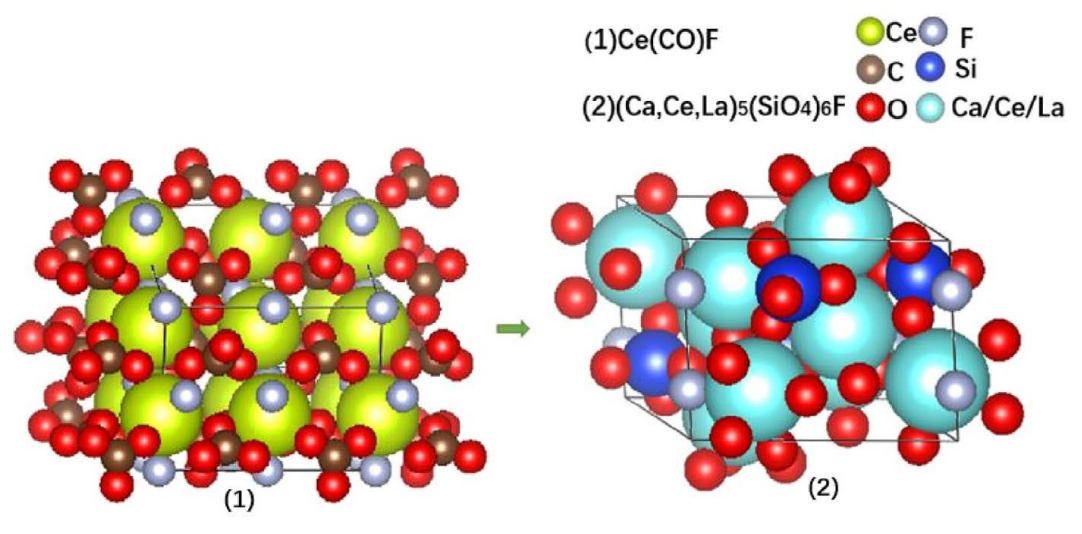

Fig. 13. Structural Charts of $\mathrm{Ce}\left(\mathrm{CO}_{3}\right) \mathrm{F}$ and $(\mathrm{Ca}, \mathrm{Ce}, \mathrm{La})_{5}\left(\mathrm{SiO}_{4}\right)_{6} \mathrm{~F}$. (Online version in color.)

$\mathrm{F}$ is smaller than the $\mathrm{R} 1=0.0233$ obtained by not adding $\mathrm{F}$, thus $\mathrm{F}$ is considered to exist. However, $(\mathrm{Ca}, \mathrm{Ce}, \mathrm{La})_{5}\left(\mathrm{SiO}_{4}\right)_{6} \mathrm{~F}$ and $\mathrm{Ca}_{3} \mathrm{Ce}_{2}\left[(\mathrm{Si}, \mathrm{P}) \mathrm{O}_{4}\right]_{3} \mathrm{~F}$ are isomorphic, and both of their space groups are P $63 / \mathrm{m}$. During the structural analysis, P was added to the structure of the RE phase, but the addition of $\mathrm{P}$ caused the structure to collapse. Attempts to add other elements that appear in the parsing structure were unsuccessful. On the basis of these results, we considered $(\mathrm{Ca}, \mathrm{Ce}$, $\mathrm{La})_{5}\left(\mathrm{SiO}_{4}\right)_{6} \mathrm{~F}$ to be the crystal structure of the RE phase. The structural data of $\mathrm{Ce}\left(\mathrm{CO}_{3}\right) \mathrm{F}^{31)}$ and $(\mathrm{Ca}, \mathrm{Ce}, \mathrm{La})_{5}\left(\mathrm{SiO}_{4}\right)_{6} \mathrm{~F}$ were used to draw the structure in Fig. 13. The $\mathrm{Ce}\left(\mathrm{CO}_{3}\right) \mathrm{F}$ in REBOCIO is convcerted into $(\mathrm{Ca}, \mathrm{Ce}, \mathrm{La})_{5}\left(\mathrm{SiO}_{4}\right)_{6} \mathrm{~F}$ by the reduction reaction that takes place during the melting process, which not only changes the composition, but also results more complicated structure.

\section{Conclusions}

The isothermal reduction and melting separation experiments of rare earth element-bearing iron carbon composite pellets were carried out. The reduction mechanism of REBOCIO and characterization of RE slag were studied in detail. The conclusions are summarized as follows.

(1) The metallization rate of the carbon-bearing pellet closely depends on the temperature, time and $\mathrm{C} / \mathrm{O}$ ratio. This experiment indicated that it would be appropriate to reduce REBOCIO at $1200^{\circ} \mathrm{C}$ for $15 \mathrm{~min}$ with a $\mathrm{C} / \mathrm{O}$ ratio of 1.2 .

(2) At a relatively low temperature of $1100^{\circ} \mathrm{C}$, the major RE-containing phase in the slag is $\mathrm{La}_{4.67}\left(\mathrm{Si} \mathrm{O}_{4}\right)_{3} \mathrm{O}$. However, $(\mathrm{Ca}, \mathrm{Ce}, \mathrm{La})_{5}\left(\mathrm{SiO}_{4}\right)_{6} \mathrm{~F}$ becomes the RE phase in the slag at $1400^{\circ} \mathrm{C}$.

(3) After melting and separation at $1400^{\circ} \mathrm{C}$, the main crystalline phases in the slag are cuspidine $\left(\mathrm{Ca}_{4} \mathrm{Si}_{2} \mathrm{O}_{7} \mathrm{~F}_{2}\right)$, $(\mathrm{Ca}, \mathrm{Ce}, \mathrm{La})_{5}\left(\mathrm{SiO}_{4}\right)_{6} \mathrm{~F}$ and fluorite $\left(\mathrm{CaF}_{2}\right)$.

(4) The size of the rare earth phase increases obviously with the decrease of cooling rate. By means of furnace cooling, the rare earth phase in the slag has a more complete structure which is hexagonal prism.

(5) The RE phase $(\mathrm{Ca}, \mathrm{Ce}, \mathrm{La})_{5}\left(\mathrm{SiO}_{4}\right)_{6} \mathrm{~F}$ in the slag is that with space group $\mathrm{P} 63 / \mathrm{m}$ and unitcell parameters $\mathrm{a}=$ 9.5908(3) $\AA, \mathrm{b}=9.5908(3) \AA, \mathrm{c}=7.0268(2) \AA, \beta=90(3)^{\circ}$, and $\mathrm{V}=559.75(4) \AA^{3}$.

(6) In order to effectively recover rare earth elements, after slag and iron are melted and separated, the cooling rate can be reduced to enrich and grow rare earth phase $(\mathrm{Ca}, \mathrm{Ce}, \mathrm{La})_{5}\left(\mathrm{SiO}_{4}\right)_{6} \mathrm{~F}$.

\section{Acknowledgements}

This work was supported by the National Natural Science Foundation of China (No. 51874029), the State Key Laboratory of Advanced Metallurgy Self-owned Fund (No. 41617015), and the Undergraduate Innovation Fund (No. 1917004).

\section{REFERENCES}

1) E. C. T. Chao, J. M. Back, J. A. Minkin and R. Yinchen: Appl. Geochem., 7 (1992), 443.

2) X. Lan, J. Gao, Y. Du and Z. Guo: J. Alloy. Compd., 731 (2018), 873.

3) M. P. Smith, P. Henderson and Z. Peishan: Contrib. Mineral. Petrol., 134 (1999), 294.

4) K. F. Yang, H. R. Fan, M. Santosh, F. F. Hu and K. Y. Wang: Ore Geol. Rev., 40 (2011), 122.

5) Y. Kanazawa and M. Kamitani: J. Alloy. Compd., 408-412 (2006), 1339.

6) Y. Liu, Z. Wen, G. Lou, Z. Li, H. Yong and X. Feng: Metall. Mater. Trans. B, 45 (2014), 2370.

7) R. Zhu, J. Ren, G. Liu, T. Wan and M. Xu: J. Univ. Sci. Technol. Beijing, 29 (2007), 172.

8) Y. Iguchi and S. Endo: ISIJ Int., 44 (2004), 1999.

9) Y. Iguchi and S. Endo: ISIJ Int., 44 (2004), 1991.

10) J. Zhang, X. Xing, M. Cao, K. Jiao, C. Wang and S. Ren: J. Iron Steel Res. Int., 20 (2013), 1.

11) X. Y. Ning, Q. G. Xue, G. Wang, F. B. Zeng, X. F. She and J. S. Wang: Ironmaking Steelmaking, 41 (2014), 583.

12) H. M. Long, J. X. Li, P. Wang and S. Q. Shi: Ironmaking Steelmaking, 39 (2012), 585.

13) Y. Ding, J. Wang, G. Wang and Q. Xue: ISIJ Int., 52 (2012), 1772.

14) Y. Ding, Q. Xue, G. Wang and J. Wang: Metall. Mater. Trans. B, 44 (2013), 28 .

15) X. She, Y. Zhao, F. Feng and J. Wang: Ironmaking Steelmaking, 44 (2017), 430.

16) D. Li, Q. Bo, T. Lou and Z. Sui: J. Iron Steel Res., 16 (2004), 30.

17) J. Li and Z. Guo: Metall. Mater. Trans. B, 45 (2014), 1272.

18) Y. Wang and Z. Yuan: Int. J. Miner. Process., 81 (2006), 133.

19) D. Chen, B. Song, L. Wang, T. Qi, Y. Wang and W. Wang: Miner. Eng., 24 (2011), 864.

20) H. Lv, H. Tu, B. Zhao, Y. Wu and K. Hu: Solid State Ion., 177 (2007), 3467.

21) X. She, J. Wang, F. Feng, G. Wang and Q. Xue: Chin. J. Rare Met., 41 (2017), 72.

22) J. Yang, T. Mori and M. Kuwabara: ISIJ Int., 47 (2007), 1394.

23) T. Ma, X. She, F. Feng and J. Wang: The Minerals, Metals \& Materials Series, Springer, Cham, (2018), 413.

24) J. Xiang, C. Zhang, G. Tu and C. Ren: Trans. Nonferr. Met. Soc. China, 4 (1994), 34

25) C. Gaillard, N. Chevarier, C. Den Auwer, N. Millard-Prinard, P. Delichère and Ph. Sainsot: J. Nucl. Mater., 299 (2001), 43.

26) M. Fleet, X. Liu and Y. Pan: J. Solid State Chem., 149 (2000), 391.

27) M. Fleet and Y. Pan: Eur. J. Mineral., 7 (1995), 591.

28) J. Hughes, M. Cameron and A. Mariano: Am. Mineral., 76 (1991), 1165 .

29) P. Comodi, Y. Liu, F. Stoppa and A. Woolley: Mineral. Mag., 63 (1999), 661.

30) G. M. Sheldrick: SHELXTL, Program for crystal structure solution, version 2014/4, Bruker AXS, Madison, WI, (2014).

31) Y. Ni, J. Hughes and A. Mariano: Am. Mineral., 78 (1993), 415. 